\title{
REVIEW
}

\section{Seagrass Meadows under the Changing Climate: A Review of the Impacts of Climate Stressors}

\author{
Kuok Ho Daniel Tang ${ }^{1 *}$ Tony Hadibarata ${ }^{2}$ \\ 1. Environmental Science Program, Division of Science and Technology, Beijing Normal University - Hong Kong \\ Baptist University United International College, Zhuhai, Guangdong, 519087, China \\ 2. Environmental Engineering Program, Faculty of Engineering and Science, Curtin University Malaysia, CDT 250, \\ Miri, Sarawak, 98009, Malaysia
}

\section{ARTICLE INFO}

Article history

Received: 19 January 2022

Accepted: 16 February 2022

Published: 23 February 2022

\section{Keywords:}

Climate change

Extreme weather

Seagrass

Ocean warming

Ocean acidification

Vulnerability

\begin{abstract}
Seagrass meadows provide important ecological functions, particularly by serving as carbon sinks and breeding grounds for marine species. Climate change has threatened seagrass communities, causing their replacement, loss and increased vulnerability. This review examined scholarly articles published between 2010-2021 to comprehensively present the impacts of climate change on seagrass meadows. It shows that ocean warming negatively affects seagrass communities by favouring communities of lower structuring capacities, thus reducing the effectiveness of their ecological functions. Ocean warming also promotes the propagation and spread of invasive species, and changes the trophic structures leading to further loss of seagrasses of value. Higher seawater temperature is associated with shoot mortality and retarded growth of certain seagrasses. Sea level rise causes more wave energy to be received by coastal seagrass communities, thus, creating more damage to the communities. Deepening sea limits light penetration and alters distribution of seagrass meadows. Carbon dioxide enrichment of seawater increases photosynthetic rate of seagrasses but ocean warming and acidification counteract this beneficial effect. Carbon dioxide enrichment affects different seagrass species and different parts of a seagrass species differently, and, where beneficial to seagrass communities, could enhance their ecological services. Temperature extremes could kill seagrasses while marine heatwaves and flooding could act synergistically to increase carbon demand of certain seagrasses and unfavourably change their biomass. These impacts are often aggravated by anthropogenic activities. This review calls for more studies and conservation efforts to understand the impacts of climate change on seagrass communities and future-proof them against the changing climate.
\end{abstract}

*Corresponding Author:

Kuok Ho Daniel Tang,

Environmental Science Program, Division of Science and Technology, Beijing Normal University - Hong Kong Baptist University United International College, Zhuhai, Guangdong, 519087, China;

Email: daniel.tangkh@yahoo.com 


\section{Introduction}

Seagrasses are marine macrophytes, commonly found at the coasts or submerged in the coastal marine environment. They are angiosperms, thus capable of flowering and are thought to have evolved from terrestrial monocots. They have well-developed rhizomes and roots which allow them to grow extensively into meadows ${ }^{[1]}$. Due to the ability of seagrasses to photosynthesize, seagrass meadows are often regarded as important carbon sinks and one of the most productive ecosystems supporting various lifeforms ${ }^{[2]}$. The requirement of light for photosynthesis defines the distribution of seagrasses in the photic zone of shallow coastal waters. Their roots penetrate into substrates such as sand or mud ${ }^{[3]}$.

Seagrass meadows could be made up of few dominant species such as those in the temperate zones, or diverse species as the tropical ones ${ }^{[3]}$. They have important ecological functions, providing habitats to different species comprising fish, mollusks, nematodes as well as epiphytic and free-living microalgae ${ }^{[4]}$. Being primary producers, seagrasses provide food to a myriad of animals like manatees, fish, sea urchins, crabs and green turtles. They are also breeding grounds for fish species ${ }^{[4]}$. Besides, seagrass meadows could act as sediment traps to filter sediment, thus reducing sediment loads, improving water quality and benefiting other ecosystems particularly the coral reefs ${ }^{[5]}$. Seagrasses modify the surrounding ecosystems, for instance, through oxygenating the sediment to support benthic organisms, and reducing wave energy to buffer against coastal erosion and storm surge ${ }^{[5]}$. Furthermore, the efficient photosynthetic capability of seagrasses permits them to pump oxygen into water while sequestering twice the amount of carbon dioxide a rainforest of equivalent area can hold. This is translated to approximately 27.4 million tonnes per hectare of $\mathrm{CO}_{2}$ annually ${ }^{[6]}$.

The changing climate has put the seagrass meadows at risk. Seagrasses are susceptible to temperature variation and ocean warming could be harmful to them ${ }^{[7]}$. Temperature anomalies have been reported with high confidence across all regions of the world and the global ocean heat content has been on a constant rise ${ }^{[8]}$. Global surface temperature recorded a rise of $1.09{ }^{\circ} \mathrm{C}$ in $2011-2020$ against the 1850-1900 baseline and anthropogenic warming likely contributed to $1.07{ }^{\circ} \mathrm{C}$ of the recorded rise. It has been projected that the average global surface temperature between 2081 and 2100 is very likely $1.0^{\circ} \mathrm{C}-1.8{ }^{\circ} \mathrm{C}$ higher than the baseline under low $\mathrm{CO}_{2}$ emission scenarios, and $3.3{ }^{\circ} \mathrm{C}-5.7{ }^{\circ} \mathrm{C}$ higher under high $\mathrm{CO}_{2}$ emission scenarios [9]. In particular to the ocean, globally, ocean has warmed with certainty over the past $40-60$ years, caused mainly by anthropogenic factors since 1970s, and the salinity difference between the upper and lower ocean has widened since the $1950 \mathrm{~s}{ }^{[9,10]}$. Besides, for the past 40 years, the ocean has been increasingly acidified and marine heatwaves as a result of anthropogenic warming had occurred at higher frequency in the $20^{\text {th }}$ century ${ }^{[9]}$. Oxygen levels of ocean have been reported to decline in many places since 1950 while ocean warming will likely happen at twice the rate observed since 1971, by 2100 according to a low warming scenario ${ }^{[9]}$.

With these changes in the ocean associated with global warming which will likely continue or intensify in the future depending on the warming scenarios, the seagrasses have been and will continue to be impacted ${ }^{[11]}$. The impacts of climate change on seagrasses are frequently exacerbated by human activities and development, which further increase their vulnerability and loss ${ }^{[12,13]}$. Over the recent years, there has been increasing interest in the research on how climate change affects seagrasses, resulting in the publication of numerous papers in this tract. These papers are largely region-specific with those probing the influences of climate change, particularly ocean warming, on Mediterranean seagrass meadows more predominant ${ }^{[14-18]}$. There are reviews looking into the stress resulted from extreme weather events on particular seagrass communities ${ }^{[19,20]}$. Besides, studies on how climate change alters host-pathogen dynamics of seagrasses ${ }^{[21,22]}$ and the change in seagrass distributions due to climate change ${ }^{[23]}$ have been conducted. Nonetheless, there are limited reviews that put all the information together systematically to critically illustrate the impacts of various facets of climate change on seagrasses.

As such, this review aims to systematically and critically present the impacts of multiple aspects of climate change on seagrass meadows. By doing so, it enables specific strategies to conserve seagrass communities to be devised. This review also highlights the challenges currently faced in the studies of how climate change affects seagrass communities as well as provides recommendations for further studies in this domain and conservation efforts to future-proof seagrass communities against climate change.

\section{Methods}

This literature review retrieved scholarly articles, primarily journal articles from established journal databases particularly Web of Science, Scopus and ScienceDirect ${ }^{[24,25]}$. The search was conducted with keywords such as climate change, seagrasses, climate change impacts on seagrasses, ocean warming, ocean acidification, extreme weather and seagrass meadows. Keywords such as climate change were entered together with other keywords 
such as seagrasses and seagrass meadows into the search engines of the respective journal databases. Likewise, ocean warming, ocean acidification and extreme weather were also coupled with seagrasses and seagrass meadow to yield meaningful search results. The key phrase 'climate change impacts on seagrasses' was entered independently. Article selection was guided by these inclusion criteria:

1) The articles were published between 2010-2021.

2) The articles are mainly about the impacts of different aspects of climate change on different species of seagrasses.

3) The articles might center on the influence of climate change on pathogens which in turn affect seagrasses.

Articles focusing on the roles of seagrasses on the eco- system and management approaches of seagrasses, as well as those on the impacts of anthropogenic activities alone are excluded from the review. The screening and selection of articles for this review are shown in Figure 1.

The screening yielded articles mainly for three regions, namely the Mediterranean which are most abundant, followed by Australia and few for the Pacific Islands, thus, implying an imbalance in research activities of this domain across the globe with most of the research focusing on the Mediterranean and Australia (Figure 2). A large proportion of the articles are general, illustrating the overall impacts of a particular aspect of climate change on seagrasses without making regional distinction.

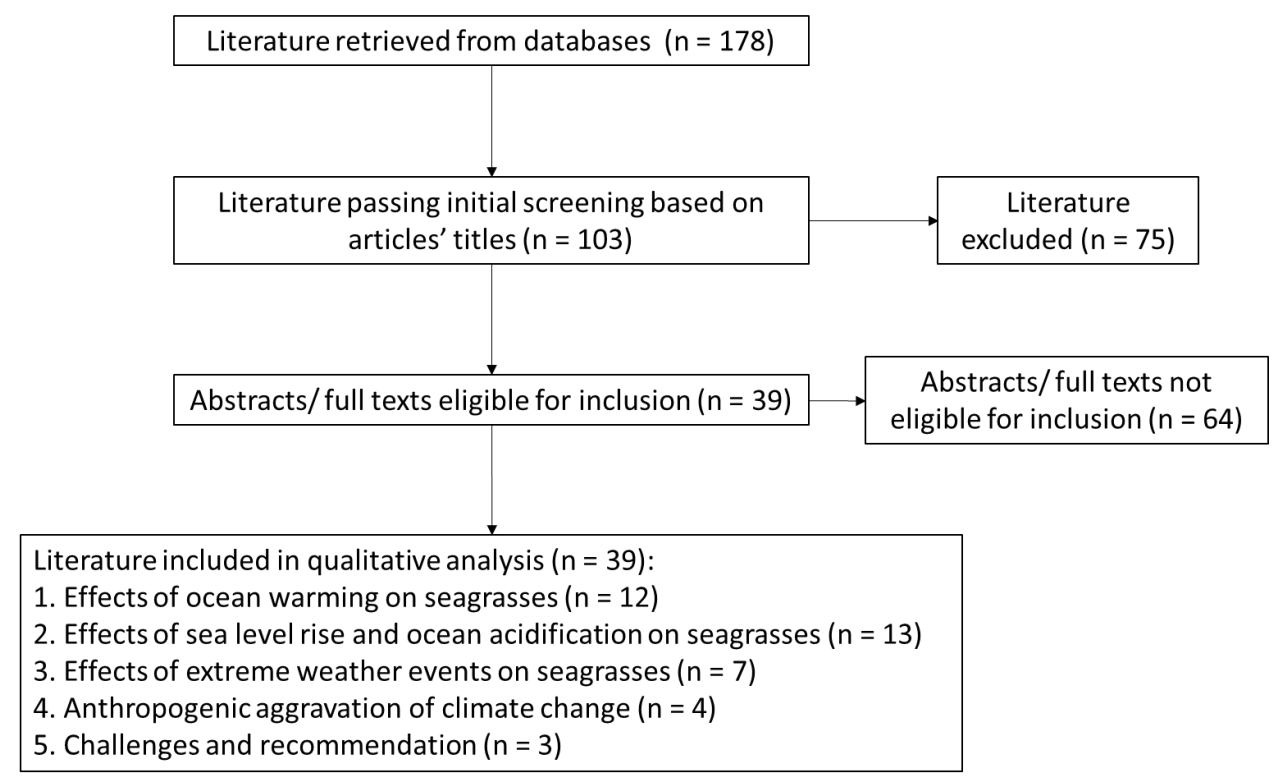

Figure 1. Screening of articles for review based on the inclusion criteria stated. Note: Some articles may be used in more than one sections of this review and their classifications were based on the predominant contents

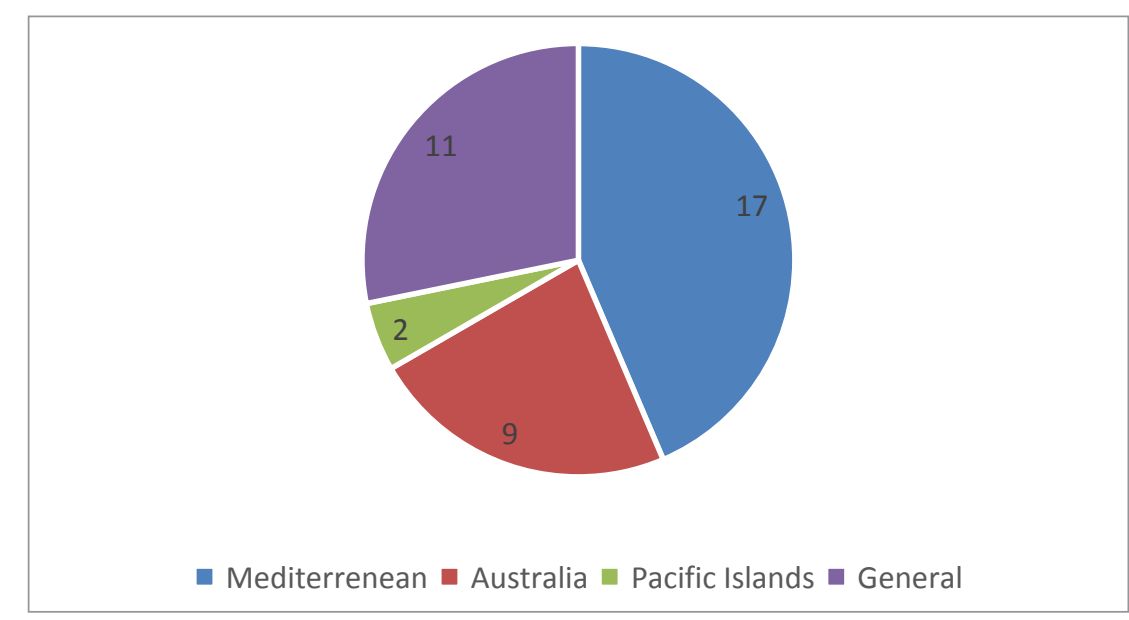

Figure 2. Number of articles reviewed according to regions 


\section{Effects of Ocean Warming on Seagrasses}

As seagrasses are particularly sensitive to temperature changes, ocean warming is detrimental to seagrass meadows. As climate change unfolds, warming of the Mediterranean Sea has been alarming. The rise in maximum annual temperature of the Mediterranean Sea has resulted in higher seagrass mortality. Further and continuous warming of the western Mediterranean could potentially cause functional extinction of Posidonia oceanica, a widely researched seagrass species, by the mid- $21^{\text {st }}$ century even when greenhouse-gas emissions were projected to be mild ${ }^{[14]}$. Higher sea temperature has been associated with substantial losses of carbon storage abilities of seagrass communities in Australia ${ }^{[26]}$. It is anticipated that seagrasses show differential sensitivity to ocean warming and there is currently a lack of studies to draw a comprehensive picture. Generally, tropical seagrasses have higher thermal tolerance than temperate ones. Some tropical species could survive at a temperature of $32{ }^{\circ} \mathrm{C}$ and most tropical species have higher temperature threshold for growth ${ }^{[27]}$.

Besides, ocean warming may result in a net negative impact on the growth of seagrasses in spite of the benefits of carbon dioxide enrichment, thus resulting in a net loss of seagrass communities particularly in the tropics ${ }^{[9]}$. In relation to the Mediterranean seagrasses, different seagrass meadows demonstrate different level of complexity and Posidonia oceanica communities distributed over the shallow coasts of the Mediterranean have the highest structural complexity ${ }^{[28]}$. However, the changing climate could affect their substitution by other seagrass species with lower structuring capacities thus affecting their ecological functions. Increased dissolution of carbon dioxide might raise the thermal optima and resistance of Posidonia oceanica, a C3 species, thus, partially offsetting the adverse impacts of ocean warming ${ }^{[29]}$. On the other hand, ocean warming will likely result in the displacement of Zostera marina by other seagrass species such as Cymodocea nodosa and Halophila stipulacea or invasive species like Womersleyella setacea which thrive in warmer environment. The displacement yields a significantly lower structural complexity and it is worsened by the potential displacement of Posidonia oceanica ${ }^{[30]}$.

Increased sea surface temperature has resulted in a quicker spread of invasive species entering from the Suez Canal into the Mediterranean ${ }^{[31]}$. These invasive species could pose significant threat to the ecological functions of the seagrass meadows in the region. An instance is the arrival of invasive herbivorous fish species which could give rise to competition with Mediterranean herbivorous species such as Sarpa salpa and Sparisoma cretense, creating a large herbivore pressure and causing overgrazing of seagrasses ${ }^{[32]}$. This could promote the colonization of seagrasses with anti-herbivore defenses such as Caulerpa spp. and Womersleyella setacea ${ }^{[33]}$.

A study tracking the correlation between seawater temperature and annual Posidonia oceanica shoot mortality in Western Mediterranean revealed that the mortality rates of Posidonia oceanica varied in the range of $0.067 /$ year and 0.123 year within the study period as $1{ }^{\circ} \mathrm{C}$ warming was recorded, leading to an average annual decline of $\mathrm{Po}_{\mathrm{O}}$ sidonia oceanica meadows by $0.050 \pm 0.02^{[16]}$. The study highlights that warming is particularly harmful to Posidonia oceanica meadows as it induces shoot mortality and it had been approximated that with every degree increase in annual maximum temperature, shoot mortality rates would increase by $0.022 /$ year $^{[16]}$. In line with these findings, Olsen et al. examined how the seedlings of Posidonia oceanica were affected by experimental warming based on the projected warming of the Mediterranean Sea and reported reduced growth rates, leaf formation rates and leaf biomass per shoot of the seedlings ${ }^{[17]}$. At $32{ }^{\circ} \mathrm{C}$, Posidonia oceanica population reduced by $0.005 /$ day. Nonetheless, in the study, Cymodocea nodosa showed greater tolerance to warming. Warming promoted rhizome growth of $C y$ modecea nodosa while positive effects were also observed for aboveground/belowground biomass, leaf biomass and population growth up to approximately $29{ }^{\circ} \mathrm{C}-30{ }^{\circ} \mathrm{C}$ after which negative effects predominated ${ }^{[17]}$. Potential replacement of Posidonia oceanica by smaller seagrass species such as Cymodocea nodosa could reduce the effectiveness of coastal protection conferred by the dead leaves of $\mathrm{Po}_{\mathrm{O}}$ sidonia oceanica which gathered onshore, producing a strong compact structure called "banquttes" [28].

\section{Effects of Sea Level Rise and Ocean Acidification on Seagrasses}

The rising sea level will cause more wave energy to propagate to the sheltered lagoons where seagrass communities are commonly found, as reefs are further away from sea surface. This exposes seagrasses to the damaging effects of waves ${ }^{[34]}$. Nonetheless, it is foreseen that the effects of sea level rise on seagrasses will not be uniform because the extents of sea level rise differ across regions though sea level rise has been projected throughout most 


\section{Sea level rise}

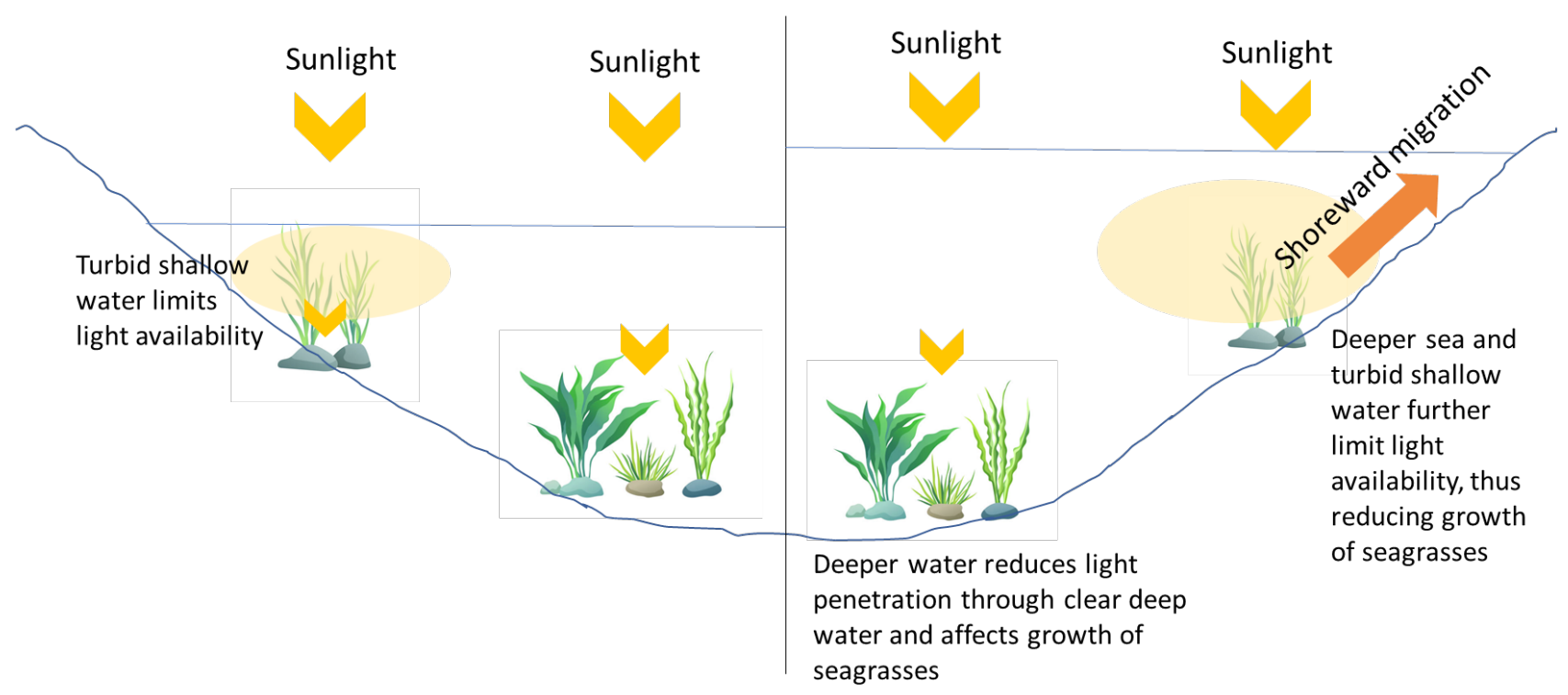

Figure 3. Impacts of sea level rise on seagrass communities

parts of the world ${ }^{[10]}$. Saunders et al. projected that a sea level rise of $1.1 \mathrm{~m}$ by 2100 corresponds to $17 \%$ loss of seagrass area ${ }^{[34]}$. Despite, with less light penetration as seawater deepens, some seagrass communities have demonstrated adaptation by growing towards the land particularly where there are extensive shallow mudflats ${ }^{[27]}$ (Figure 3). This adaptation could be hampered by human activities such as coastal development and land reclamation $^{[8]}$.

Continuous rise in carbon dioxide level will cause more carbon dioxide to dissolve in seawater and reduce its $\mathrm{pH}$. Carbon dioxide enrichment of seawater is likely to increase the photosynthetic activity of seagrasses ${ }^{[1]}$ leading to significantly higher productivity and carbon sequestration of certain seagrass communities ${ }^{[2]}$ (Figure 4). The increased carbon storage by seagrasses implies a localized counteraction of ocean acidification. In the long-term, the effects of higher dissolved carbon dioxide in seawater remain uncertain ${ }^{[35]}$. However, in instances where seagrass communities are benefited from carbon dioxide enrichment, the associated ecosystem services will also increase, resulting in enhancement of richness and productivity of seagrass-based food chains as well as the shelter they provide for aquatic lives ${ }^{[37]}$. As marine en- vironment changes and is increasingly acidified, tropical seagrass communities could serve as refugia for marine invertebrates ${ }^{[38]}$. In spite of this, whether a seagrass community would flourish with carbon dioxide enrichment depends on the ability of the seagrasses to use the higher level of dissolved inorganic carbon in seawater effectively since anthropogenic activities also pollute the marine environment, for instance, through surface runoffs ${ }^{[39]}$.

In the Mediterranean, decline in seawater $\mathrm{pH}$ to as low as 6.57 after volcanic carbon dioxide emissions caused a significant reduction in the population of calcified organisms and corallines in seagrass meadows while promoting the growth of fleshy macroalgae. Overgrowth of fleshy macroalgae blocked penetration of light, causing seagrasses to regress at a faster rate despite carbon dioxide enrichment ${ }^{[29]}$. This also stripped the potential benefit of higher photosynthesis by seagrass meadows due to carbon dioxide enrichment, which could restore the $\mathrm{pH}$ of shallow bays and coastal lagoons for calcification to occur ${ }^{[40]}$. Similar impacts could be observed with increased dissolution of atmospheric carbon dioxide in seawater as emission of climate changing greenhouse gases intensifies, favoring the growth of non-native or invasive species. 


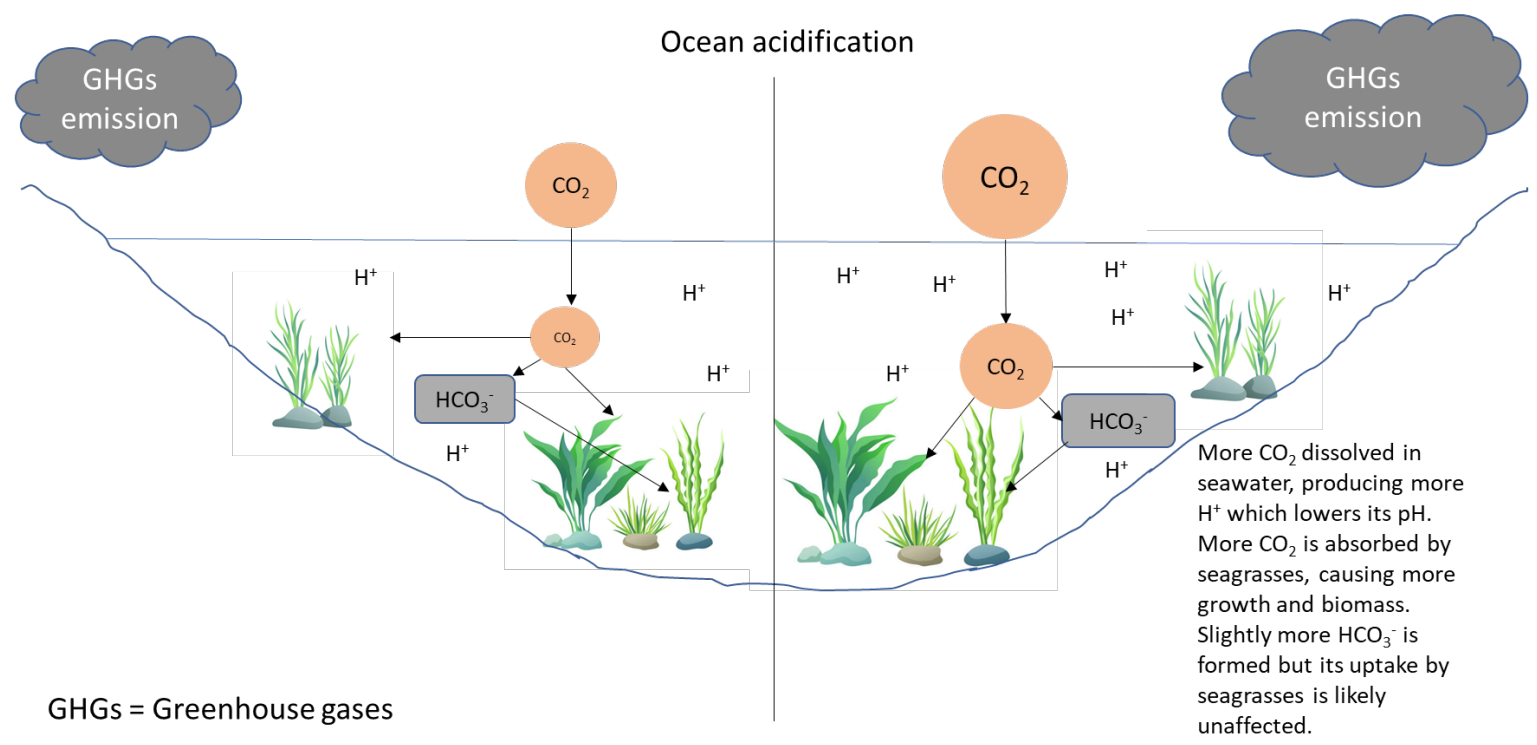

Figure 4. Effects of ocean acidification on seagrass communities

\section{Effects of Extreme Weather Events on Sea- grasses}

Temperature extremes could produce detrimental effects on the growth of seagrasses and kill them ${ }^{[4]}$. Ocean warming, characterized by more heat in seawater, fuels extreme weather events such as tropical cyclones and storms, leading to damages to seagrass communities as well as deterioration of seawater quality through resuspension of sediments which interferes with photosynthesis and growth of seagrasses ${ }^{[7]}$. This threatens the resilience and productivity of seagrass communities. In Western Australia, a marine heatwave and floods occurring in 2010-2011 resulted in severe deleterious response of Amphibolis antarctica, a temperate seagrass. Profuse defoliation of Amphibolis antarctica occurred for months after the extreme events and was most severe at sites impacted by flooding ${ }^{[20]}$. It was thought that marine heatwaves and floods acted synergically to increase the carbon demand of Amphibolis antarctica. Higher temperatures associated with heatwave could raise the carbon demand of Amphibolis antarctica and flooding increased turbidity of seawater which reduced the amount of light reaching the seagrass, causing the seagrass to have a negative carbon balance $^{[20]}$.

For two years subsequent to the extreme weather events, the below-ground biomass of Amphibolis antarctica declined by an order of magnitude and this implies reduced resilience of Amphibolis antarctica to future climate variations ${ }^{[20]}$. Therefore, multiple stressors brought forth by extreme weather events could give rise to synergistic impacts which trigger severe ecological responses, especially for species already approaching their upper thermal tolerance in an ecosystem ${ }^{[20]}$. Furthermore, unseasonal rainfall during dry season is classified as an extreme weather event of estuarine catchments. It could change estuarine salinity gradients, hence the ecosystem therein. In southwestern Australia, a gush of freshwater into an estuary during an extreme rainfall event in 2017 altered the biomass of Halophila ovalis ${ }^{[42]}$. In estuarine areas with variable salinity, the seagrass communities demonstrated more plastic salinity tolerance and their reduced biomass recovered within 9 to 11 months. In areas with more constant salinity, the ensuing loss of biomass was more significant and the recovery took more than 22 months ${ }^{[42]}$. The responses of seagrasses to variations in salinity are often population-specific.

A review of the impacts of a marine heatwave in Western Australia which sent the coastal water temperature $4{ }^{\circ} \mathrm{C}$ higher than it would normally be in the summer revealed the taking over of certain areas experiencing losses of dominant seagrass by small fast-growing tropical species such as Halodule uninervis ${ }^{[19]}$. This subsequently disrupted the species dynamics, ecosystem recovery and trophic structures. Similarly, the summer marine heatwaves hitting Chesapeake Bay between 2005 and 2010 wiped out $58 \%$ of Zostera marina, leading to a subsequent fall in the populations of blue crabs, silver perch and bay scallops ${ }^{[43]}$. Furthermore, severe storms were found to result in tropical seagrass decline in north Queensland, Australia, particularly the shallow and deep seagrass communities. Recovery of deep seagrass communities, especially those of Halophila spp. was most evident two years after the loss owing to the presence of seed banks 
but recovery of the shallow species after being experimentally disturbed was tardy due to a lack of seed banks and dependence on asexual propagation ${ }^{[44]}$.

\section{Aggravation of Climate Change Impacts by Anthropogenic Factors}

According to Cullen-Unsworth and Unsworth ${ }^{[4]}$, seagrass meadows are declining globally at a rate of more than $7 \%$ per year, attributed primarily to human activities and secondarily to climate change. This points to the escalation of seagrass loss by anthropogenic factors as seagrasses are already under the threat of global climate change. In relation to global warming alone, in Australia, significant loss of sequestered carbon in seagrasses had been reported after episodes of seawater temperature hike ${ }^{[26]}$. Waycott et al. projected a $5 \%$ to $35 \%$ of shrinkage in seagrass habitats by 2100 as global warming continues ${ }^{[37]}$. The extent of seagrass loss is potentially correlated to population sizes, which again, points to anthropogenic influence behind the loss ${ }^{[4,27]}$. In fact, anthropogenic factors account for a significant part of climate change, resulting in phenomena comprising global warming, sea level rise, ocean acidification as well as intensification of storms and waves ${ }^{[45]}$.

Furthermore, human activities such as agriculture have led to the entry of nutrients into waterbodies. Algal bloom due to nutrient enrichment of seawater will adversely affect the growth of seagrasses and this is worsened by increased turbidity of seawater due to pollution which reduces the light reaching seagrasses ${ }^{[46,47]}$. Coastal development such as construction of ports, harbors, embankments and artificial beaches has resulted in the loss of shallow seagrass communities which play important roles in attenuating the wave energy coming to the shore, hence the coastal erosion caused. While climate change plays a role in the shrinkage of seagrass areas, it is not solely to be blamed since human impacts have accounted for the larger proportion of seagrass loss and resulted in reduced resilience of seagrasses against climate change ${ }^{[18]}$.

\section{Challenges and Recommendations}

As seagrasses are increasingly threatened by human activities and the changing climate, there are challenges that face the accurate identification of how these factors influence seagrasses. The monitoring and mapping of seagrass distribution have been particularly challenging owing to their wide distribution and a current lack of studies focusing on this area. The mapping of seagrass communities worldwide has not progressed substantially, leaving many communities uncharted, especially in developing countries
${ }^{[48]}$. Besides, remote sensing technology is limited in sensing deep water seagrasses or those in complex seascapes and turbid environment ${ }^{[49]}$. The inherently dynamic nature of seagrass communities also complicates seagrass mapping because seagrass distribution could change naturally without human interference.

In addition, the impacts of climate change on seagrasses are often species and population specific and it may involve voluminous studies to understand how different species and communities of seagrass respond to various climate stressors ${ }^{[42]}$. Climate stressors frequently work together instead of separately to affect seagrass meadows. The synergistic impacts of multiple climate stressors on seagrasses make the studies more complex ${ }^{[19]}$. Climate change could also indirectly affect seagrass health through altering pathogen distribution. Climate warming has been deemed to work in tandem with hypersalinity and eutrophication to increase seagrass disease outbreaks. These stressors could lower seagrass resilience against pathogen while promoting pathogen development ${ }^{[2]}$. The area of seagrass-pathogen dynamics remains inadequately understood and this calls for more studies. In view of the challenges related to the study of climate change impacts on seagrasses, the following recommendations are made:

1) There is a need to extend the studies of seagrasses in relation to the changing climate. Currently, most of the published literature about the impacts of climate change on seagrasses is limited to the Mediterranean and Australia. There are few studies on those of the Pacific Islands. It is crucial to conduct more regional studies to examine how climate stressors act independently and in synergy on seagrasses and seagrass communities.

2) To understand how seagrass communities have changed spatially and temporally with the changing climate, there is a need to conduct more extensive mapping to obtain the baseline or variations of the seagrass communities globally.

3) The vulnerability of seagrasses to climate change differs. Seagrass meadows in shallow waters are more susceptible to climate change due to limited water exchange in transitional zones ${ }^{[30]}$. It is therefore, important to study the vulnerability of different seagrass communities to climate change to step up conservation effort.

4) Resilience of seagrass communities is greatly affected by anthropogenic activities which have been shown to be more damaging than the impacts of climate change. Controlling anthropogenic activities which threaten seagrass communities is also a way of future-proofing seagrass communities against the impacts of climate change.

5) It is also imperative to develop a better understanding of the interconnection between seagrass meadows and 
other coastal or near-shore resources such as mangroves and coral reef, especially the joint ecological functions. It is likely that these coastal communities could affect each other ${ }^{[50]}$.

6) Raising awareness of the ecological importance of seagrass communities and building capacity in their conservation could contribute significantly to the resilience of seagrass communities.

\section{Conclusions}

This review shows that climate change has given rise to multiple impacts on seagrass communities. Seagrasses are sensitive to ocean warming and the sensitivity is often species-specific with some species having higher thermal tolerance than others, especially the tropical ones. Ocean warming in the Mediterranean could potentially result in mortality and substitution of Posidonia oceanica communities by smaller seagrasses, leading to severe compromise of their ecological functions. Rising sea level introduces more wave energy to sheltered lagoons where seagrasses are normally found, causing damages to seagrasses. Deeper water limits light penetration and promotes landward growth of seagrasses. Carbon dioxide enrichment of seawater could raise photosynthetic activity of seagrasses but this benefit could be offset by ocean warming and acidification. Extreme weather events introduce multiple stressors such as temperature upsurge and salinity fluctuation which could impact seagrasses synergistically. Flooding causes sediment resuspension and increased turbidity of seawater which limit light accessibility of seagrasses. This review calls for more studies related to mapping and baseline establishment of seagrass communities globally. It underscores the importance to understand how climate stressors act separately and synergistically on seagrass communities which forms an obvious gap in the study of climate change impacts on seagrasses. Understanding the differential vulnerabilities of seagrass communities would enable effective conservation of the seagrass communities through targeted resilience building. Finally, regulating anthropogenic activities is also crucial to future-proofing the resilience of seagrass communities against climate change.

\section{Conflict of Interest}

The authors declare no conflict of interest.

\section{Funding}

The study does not receive any funding.

\section{References}

[1] Repolho, T., Duarte, B., Dionísio, G., et al., 2017. Seagrass ecophysiological performance under ocean warming and acidification. Scientific Reports. 7(1), 41443.

DOI: https://doi.org/10.1038/srep41443

[2] Russell, B.D., Connell, S.D., Uthicke, S., et al., 2013. Future seagrass beds: Can increased productivity lead to increased carbon storage? Marine Pollution Bulletin. 73(2), 463-469.

DOI: https://doi.org/https://doi.org/10.1016/j.marpolbul.2013.01.031

[3] Papenbrock, J., 2012. Highlights in seagrasses' phylogeny, physiology, and metabolism: what makes them special? International Scholarly Research Notices.

[4] Cullen-Unsworth, L., Unsworth, R., 2013. Seagrass Meadows, Ecosystem Services, and Sustainability. Environment: Science and Policy for Sustainable Development. 55(3), 14-28.

DOI: https://doi.org/10.1080/00139157.2013.785864

[5] Mtwana Nordlund, L., Koch, E.W., Barbier, E.B., et al., 2016. Seagrass Ecosystem Services and Their Variability across Genera and Geographical Regions. Plos one. 11(10), e0163091.

DOI: https://doi.org/10.1371/journal.pone.0163091

[6] Macreadie, P.I., Baird, M.E., Trevathan-Tackett, S.M., et al., 2014. Quantifying and modelling the carbon sequestration capacity of seagrass meadows - A critical assessment. Marine Pollution Bulletin. 83(2), 430-439.

DOI: https://doi.org/https://doi.org/10.1016/j.marpolbul.2013.07.038

[7] Brodie, G., Holland, E., N'Yeurt, A.D.R., et al., 2020. Seagrasses and seagrass habitats in Pacific small island developing states: Potential loss of benefits via human disturbance and climate change. Marine Pollution Bulletin. 160, 111573.

DOI: https://doi.org/https://doi.org/10.1016/j.marpolbul.2020.111573

[8] Tang, K.H.D., 2019. Are We Already in a Climate Crisis? Global Journal of Civil and Environmental Engineering. 1, 25-32.

[9] IPCC, 2021. Climate Change 2021: The Physical Science Basis. Contribution of Working Group I to the Sixth Assessment Report of the Intergovernmental Panel on Climate Change.

[10] Tang, K.H.D., 2020. Implications of Climate Change on Marine Biodiversity. Global Journal of Agriculture and Soil Science. 1(1), 1-6.

[11] Tang, K.H.D., 2019) Climate change in Malaysia: Trends, contributors, impacts, mitigation and adaptations. Science of The Total Environment. 650, 1858-1871. 
DOI: https://doi.org/https://doi.org/10.1016/j.scitotenv.2018.09.316

[12] Tang, K.H.D., 2019. Impacts of Climate Change on Tropical Rainforests' Adaptive Capacity and Ecological Plasticity. Climate Change Facts, Impacts and Solutions. 1, 1-5.

[13] Tang, K., 2019. Climate change and paddy yield in Malaysia: A short communication. Global Journal of Civil and Environmental Engineering. 1, 14-19.

[14] Jordà, G., Marbà, N., Duarte, C.M., 2012. Mediterranean seagrass vulnerable to regional climate warming. Nature Climate Change. 2(11), 821-824.

DOI: https://doi.org/10.1038/nclimate1533

[15] Chefaoui, R.M., Duarte, C.M., Serrão, E.A., 2018. Dramatic loss of seagrass habitat under projected climate change in the Mediterranean Sea. Global Change Biology. 24(10), 4919-4928.

DOI: https://doi.org/https://doi.org/10.1111/ gcb. 14401

[16] Marba, N., Duarte, C.M., 2010. Mediterranean warming triggers seagrass (Posidonia oceanica) shoot mortality. Global Change Biology. 16(8), 2366-2375. DOI: https://doi.org/https://doi.org/10.1111/j.13652486.2009.02130.x

[17] Olsen, Y.S., Sánchez-Camacho, M., Marbà, N., et al., 2012. Mediterranean Seagrass Growth and Demography Responses to Experimental Warming. Estuaries and Coasts. 35(5), 1205-1213.

DOI: https://doi.org/10.1007/s12237-012-9521-z

[18] Pergent, G., Pergent-Martini, C., Bein, A., et al., 2015. Dynamic of Posidonia oceanica seagrass meadows in the northwestern Mediterranean: Could climate change be to blame? Comptes Rendus Biologies. 338(7), 484-493.

DOI: https://doi.org/https://doi.org/10.1016/j.crvi.2015.04.011

[19] Kendrick, G.A., Nowicki, R.J., Olsen, Y.S., et al., 2019. A Systematic Review of How Multiple Stressors From an Extreme Event Drove Ecosystem-Wide Loss of Resilience in an Iconic Seagrass Community. In Frontiers in Marine Science. 6, 455. https://www. frontiersin.org/article/10.3389/fmars.2019.00455

[20] Fraser, M.W., Kendrick, G.A., Statton, J., et al., 2014. Extreme climate events lower resilience of foundation seagrass at edge of biogeographical range. Journal of Ecology. 102(6), 1528-1536.

DOI: https://doi.org/https://doi.org/10.1111/13652745.12300

[21] Olsen, Y.S., Potouroglou, M., Garcias-Bonet, N., et al., 2015. Warming Reduces Pathogen Pressure on a Climate-Vulnerable Seagrass Species. Estuaries and
Coasts. 38(2), 659-667.

DOI: https://doi.org/10.1007/s12237-014-9847-9

[22] Sullivan, B.K., Trevathan-Tackett, S.M., Neuhauser, S., et al., 2018. Review: Host-pathogen dynamics of seagrass diseases under future global change. Marine Pollution Bulletin. 134, 75-88.

DOI: https://doi.org/https://doi.org/10.1016/j.marpolbul.2017.09.030

[23] Davis, T.R., Harasti, D., Smith, S.D.A., et al., 2016. Using modelling to predict impacts of sea level rise and increased turbidity on seagrass distributions in estuarine embayments. Estuarine, Coastal and Shelf Science. 181, 294-301.

DOI: https://doi.org/https://doi.org/10.1016/ j.ecss.2016.09.005

[24] Tang, K.H.D., 2021. The effects of climate change on occupational safety and health. Global Journal of Civil and Environmental Engineering. 3, 1-10.

DOI: https://doi.org/10.36811/gjcee.2021.110008

[25] Tang, K.H.D., 2021. Climate Change and Its Impacts on Mental Wellbeing. Glob Acad J Humanit Soc Sci. 3(4), 144-151.

[26] Arias-Ortiz, A., Serrano, O., Masqué, P., et al., 2018. A marine heatwave drives massive losses from the world's largest seagrass carbon stocks. Nature Climate Change. 8(4), 338-344.

DOI: https://doi.org/10.1038/s41558-018-0096-y

[27] Short, F.T., Kosten, S., Morgan, P.A., et al., 2016. Impacts of climate change on submerged and emergent wetland plants. Aquatic Botany. 135, 3-17.

DOI: https://doi.org/https://doi.org/10.1016/ j.aquabot.2016.06.006

[28] Boudouresque, C.F., Bernard, G., Bonhomme, Patrick Charbonnel, E., et al., 2012. Protection and conservation of Posidonia oceanica meadows. RAMOGE and RAC/SPA.

[29] Koch, M., Bowes, G., Ross, C., et al., 2013. Climate change and ocean acidification effects on seagrasses and marine macroalgae. Global Change Biology. 19(1), 103-132.

DOI: https://doi.org/https://doi.org/10.1111/j.13652486.2012.02791.x

[30] Pergent, G., Bazairi, H., Bianchi, C.N., et al., 2014. Climate change and Mediterranean seagrass meadows: a synopsis for environmental managers. Mediterranean Marine Science. 15(2), 462-473.

[31] Zenetos, A., Gofas, S., Morri, C., et al., 2012. Alien species in the Mediterranean Sea by 2012. A contribution to the application of European Union's Marine Strategy Framework Directive (MSFD). Part 2. Introduction trends and pathways. Mediterranean Marine 
Science. 13(2), 328-352.

[32] Sala, E., Kizilkaya, Z., Yildirim, D., et al., 2011. Alien Marine Fishes Deplete Algal Biomass in the Eastern Mediterranean. Plos One. 6(2), e17356. DOI: https://doi.org/10.1371/journal.pone.0017356

[33] Boudouresque, C.F., Ruitton, S., Verlaque, M., 2005. Large-scale disturbances, regime shift and recovery in littoral systems subject to biological invasions. Large-Scale Disturbances (Regime Shifts) and Recovery in Aquatic Ecosystems: Challenges for Management Towards Sustainability. UNESCO Publisher. pp. 85-101.

[34] Saunders, M.I., Leon, J.X., Callaghan, D.P., et al., 2014. Interdependency of tropical marine ecosystems in response to climate change. Nature Climate Change. 4(8), 724-729.

DOI: https://doi.org/10.1038/nclimate2274

[35] Takahashi, M., Noonan, S.H.C., Fabricius, K.E., et al., 2016. The effects of long-term in situ $\mathrm{CO} 2$ enrichment on tropical seagrass communities at volcanic vents. ICES Journal of Marine Science. 73(3), 876-886.

DOI: https://doi.org/10.1093/icesjms/fsv157

[36] Campbell, J.E., Fourqurean, J.W., 2013. Effects of in situ $\mathrm{CO} 2$ enrichment on the structural and chemical characteristics of the seagrass Thalassia testudinum. Marine Biology. 160(6), 1465-1475.

DOI: https://doi.org/10.1007/s00227-013-2199-3

[37] Waycott, M., McKenzie, L.J., Mellors, J.E., et al., 2011. Vulnerability of mangroves, seagrasses and intertidal flats in the tropical Pacific to climate change.

[38] Garrard, S.L., Beaumont, N.J., 2014. The effect of ocean acidification on carbon storage and sequestration in seagrass beds; a global and UK context. Marine Pollution Bulletin. 86(1), 138-146.

DOI: https://doi.org/https://doi.org/10.1016/j.marpolbul.2014.07.032

[39] Ow, Y.X., Uthicke, S., Collier, C.J., 2016. Light Levels Affect Carbon Utilisation in Tropical Seagrass under Ocean Acidification. Plos One. 11(3), e0150352. DOI: https://doi.org/10.1371/journal.pone.0150352

[40] Semesi, I.S., Kangwe, J., Björk, M., 2009. Alterations in seawater $\mathrm{pH}$ and $\mathrm{CO} 2$ affect calcification and photosynthesis in the tropical coralline alga, Hydrolithon sp.(Rhodophyta). Estuarine, Coastal and Shelf Science. 84(3), 337-341.

[41] Collier, C.J., Waycott, M., 2014. Temperature extremes reduce seagrass growth and induce mortality. Marine Pollution Bulletin. 83(2), 483-490.
DOI: https://doi.org/https://doi.org/10.1016/j.marpolbul.2014.03.050

[42] Webster, C.L., Kilminster, K.L., Sánchez Alarcón, M., et al., 2021. Population-specific resilience of Halophila ovalis seagrass habitat to unseasonal rainfall, an extreme climate event in estuaries. Journal of Ecology. 109(9), 3260-3279.

DOI: https://doi.org/https://doi.org/10.1111/13652745.13648

[43] Hobday, A.J., Oliver, E.C.J., Gupta, A., et al., 2018. Categorizing and naming marine heatwaves. Oceanography. 31(2), 162-173.

[44] Rasheed, M.A., McKenna, S.A., Carter, A.B., Coles, R.G., 2014. Contrasting recovery of shallow and deep water seagrass communities following climate associated losses in tropical north Queensland, Australia. Marine Pollution Bulletin. 83(2), 491-499.

DOI: https://doi.org/https://doi.org/10.1016/j.marpolbul.2014.02.013

[45] Tang, K.H.D., Yap, P.S., 2020. A Systematic Review of Slash-and-Burn Agriculture as an Obstacle to Future-Proofing Climate Change. Proceedings of The International Conference on Climate Change. 4(1 SE-Articles).

DOI: https://doi.org/10.17501/2513258X.2020.4101

[46] Burnell, O.W., Russell, B.D., Irving, A.D., et al., 2014. Seagrass response to CO2 contingent on epiphytic algae: indirect effects can overwhelm direct effects. Oecologia. 176(3), 871-882.

DOI: https://doi.org/10.1007/s00442-014-3054-z

[47] Choong, W.S., Hadibarata, T., Tang, D.K.H., 2020. Abundance and Distribution of Microplastics in the Water and Riverbank Sediment in Malaysia-A Review. Biointerface Research in Applied Chemistry. 11(4), 11700-11712.

[48] Unsworth, R.K.F., McKenzie, L.J., Collier, C.J., et al., 2019. Global challenges for seagrass conservation. Ambio. 48(8), 801-815.

DOI: https://doi.org/10.1007/s13280-018-1115-y

[49] Knudby, A., Nordlund, L., 2011. Remote sensing of seagrasses in a patchy multi-species environment. International Journal of Remote Sensing. 32(8), 22272244.

DOI: https://doi.org/10.1080/01431161003692057

[50] Guannel, G., Arkema, K., Ruggiero, P., et al., 2016. The Power of Three: Coral Reefs, Seagrasses and Mangroves Protect Coastal Regions and Increase Their Resilience. Plos One. 11(7), e0158094. DOI: https://doi.org/10.1371/journal.pone.0158094 